Factors Predicting the Culture Shock of Peace Corps Volunteers in the Western China Universities

Hongling Lai

Dianjian Wang ${ }^{2^{*}}$

\author{
'English Department, Lanzhou \\ Jiaotong University, Lanzhou, China. \\ Email:laihl@mail.lzjtu.cn \\ 'Center for Faculty Development, \\ Lanzhou Jiaotong University, \\ Lanzhou, China. \\ Email:wangdianjian@msn.com \\ Licensed: \\ This work is licensed under a Creative \\ Commons Attribution 4.o License. \\ Keywords: \\ Culture shock \\ Adaptation \\ Peace Corps volunteers \\ China. \\ Accepted: 2 October 2019 \\ Published: 14 October 2019
}

\begin{abstract}
This study investigated the factors predicting the culture shock of Peace Corps volunteers in the universities in the western China. The results revealed that length of stay and gender were not significant predictors for culture shock. Though no significant difference was found between length of stay and culture shock, length of stay in this study showed a negative predictive effect on culture shock. Education background was a significant negative predictor for culture shock. A strong correlation was found between culture shock and homesickness. Homesickness accounted for $53.5 \%$ of the variance in culture shock. Feelings toward China also were found to be correlated to culture shock and could account for $26.6 \%$ of variance in culture shock. Multiple Regression Analysis showed homesickness and feelings towards China had a direct effect on culture shock, satisfaction with the life in China had indirect effect on culture shock with homesickness and feelings towards China as mediating variables.
\end{abstract}

Funding: This study receive no specific financial support.

Competing Interests: The authors declare that they have no competing interests.

\title{
1. Research Background
}

In the past decades, studies about cross-cultural adjustment have made great achievements in the fields of cross-cultural models and theories (Berry, 1990; Gullahorn \& Gullahorn, 1963; Kim, Atkinson, \& Umemoto, 2001; Lysgaard, 1955; Oberg, 1960; Ward \& Kennedy, 1992). Cross-cultural adjustment is widely regarded as a potentially distressing life changing events that require a variety of affective, behavioural, and cognitive responses to the new environment (Ward \& Kennedy, 1999). Such distress experiences the sojourner often undergo as a result of losing all the familiar signs and symbols of social interaction are commonly referred to as 'culture shock' (Oberg, 1960). Culture shock aroused naturally when individuals were confronted with an unfamiliar environment, where existing familiar social patterns were rendered ineffective (Mumford, 2000). Culture shock may be understood as the stress caused by different behavioural expectations and the accompanying uncertainty that expatriates must deal with Shi and Wang (2014). Psychological crises and social dysfunctions may be provoked by culture shock reactions due to the cultural differences (Winkelman, 1994).

Most of the previous studies hypothesized culture shock as one of the initial stages of the cross-cultural adaptation in which individuals felt the stress and anxiety immediately because of the unfamiliarity of the new host culture (Adler, 1975; Gullahorn \& Gullahorn, 1963; Oberg, 1960). Though the stages of cross-cultural adaptation were described in details, they were only hypothesizes, not all the individuals had the same experiences when their familiar social norms of behaviours were replaced by a new host culture. The different individual background might affect the degree of cross-cultural adaptation, and some of the individuals even did not experience the first stage of the U-curve (Adler, 1975). Kleinberg and Hull (1979) oncluded that not all the immigrants started their adaptation from the honeymoon stages. Church (1982) thought the evidences to the U-curve were week, uncertain and over generalized.

The studies on culture shock were focused greatly on individuals' intense experiences of encountering another culture at the initial phase of culture shock (Church, 1982; Mumford, 2000). Few studies discussed whether symptoms of culture shock fluctuated according to different time-scales (Hsiao-Ying, 1995) and no 
strong evidence was found for the U-curve because of few longitudinal studies (Mumford, 2000). The empirical evidence for culture shock and its essence are weak. From developmental perspectives, studies of the psychological reactions to encountering a new host culture over time were fewer (Mumford, 2000). Whether the symptoms of culture shock diminish because of the systemic training before the expatriates enter a new host culture needs to be explored.

China has been inviting Peace Corps to work with Chinese universities to train future English teachers in the provinces that come under the Western China Development Project since 1993, which includes Sichuan, Gansu, Guizhou provinces and Chongqing Municipality (Peace Corps China, 2016). The research on the lives of Peace Corps volunteers is relatively minimal. The previous studies on psychological adaptation of Peace Corps volunteers focused mainly on traits characteristic of Peace Corps volunteers (Becker \& Eagley, 2004). The sociological research on Peace Corps volunteers has concentrated on how the social contexts, e.g., community size and types of training, made a successful Peace Corps experience possible (Guthrie \& Dan, 1967; Hare, 1966) and the influence of power structures and personal perceptions of cultural experiences (Carano, 2013). However, fewer studies examined the Peace Corp volunteers' cross-cultural experiences in the Chinese universities. Actually, $40 \%$ of Peace Corps volunteers were found to drop out either in training or in the placement and the American Peace Corps found that they were not able to predict which volunteers would experience major difficulties and could not complete their work abroad (Mumford, 2000). The increasing number of American Peace Corps volunteers as English teachers in Chinese universities poses many crosscultural challenges. The noticeable mismatch of cultural norms and language patterns between China and the U.S can result in significant cross-cultural misunderstandings and difficulties.

Therefore, a better understanding of Peace Corps volunteers' cultural adjustment as English teachers in China and addressing issues of their culture shock are crucial and necessary. To investigate the factors predicting the culture shock of Peace Corps volunteers in the western China, this research surveyed how the demographic factors, homesickness, feelings towards China, and satisfaction with the life in China were related to Peace Corps volunteers' culture shock in the western China.

\section{Related Studies \\ 2.1. Culture Shock}

As a potentially distressing life changing events, culture shock refers to the anxiety resulting from the loss of familiar signs and symbols of home social interactions (Oberg, 1960). The essence of culture shock is the continuing psychological and behavioural outcomes of acculturation process (Sumer, 2009). Psychological and socio-cultural adaptation was theorized from two divergent traditions in the "culture shock" field (Ward \& Kennedy, 1992): psychology of adjustment (Berrye, Kim, \& Boski, 1988) and social skill model (Argyle, Furnham, \& Graham, 1981). Psychological adaptation referred to the feelings of well-being, life satisfaction, and good mental health (Castro, 2003). Culture shock may be found at various levels such as homesickness, depression, frustration and anger (Black \& Gregersen, 1990). Other researchers regarded culture shock as 'language shock' focusing on difficulties in communication (Smalley, 1963) 'role shock' (Byrnes, 1966) and as an anxiety reaction to what some people could not understand, control or predict other people's behaviour (Bock, 1970). Guthries (1975) studied American Peace Corps volunteers and defined the culture shock as 'culture fatigue'. Furnham and Bochner (1986) endorsed the different aspects of culture shock identified by Taft (1977) which included strain in psychological adaptations, feelings of losing friends, status, occupation and possessions, role confusion, difficulties in adapting to a new culture, surprise, anxiety, even indignation to the cultural differences, and feelings of being unable to cope with the new culture. The present study was based on Taft's summary of the concept of culture shock.

\subsection{Homesickness}

One of the main symptoms of culture shock is homesickness, which was defined as a desire for familiar environments and included loneliness, sadness and adjustment difficulties (Hendrickson, Rosen, \& Aune, 2010; Poyrazli \& Lopez, 2007) and was described as a form of separation anxiety (Brewin, Furnham, \& Howes, 1989). Homesickness individuals yearned to be in constant communication with family members back home and withdrew from the host social activities (Messina, 2007). Researchers found that homesickness was one of the main factors to cause social alienation (Sandhu \& Asrabadi, 1994) and a predictor of psychological wellbeing (Ward \& Kennedy, 1992). As a negative cross-cultural adjustment factor, homesickness was manifested as affective difficulties and was linked with limited social contact with host culture (Hull, 1978). Loss of home social support, homesickness manifesting the culture shock might lead to adjusting difficulties (Mori, 2000). Previous studies have found that international students experienced homesickness because of culture shock (Chapdelaine \& Alexitch, 2004; Poyrazli \& Lopez, 2007). However, not much evidence of effects of work abroad on feelings of homesickness was found.

\subsection{Feelings towards the Host Culture}

The psychological approach tried to explore expatriates' attitudes to acculturation while the socio-cultural approach observed the social behaviour that exemplified these attitudes (Selmer, 1999). Yu and Huat (1995) 
revealed that the local station attitude, lack of local station competence, language, cultural differences, lack of local government support, and government policy changes were the most difficult problems perceived by expatriates. Nevertheless, Selmer (1999) speculated that psychological adjustment was more difficult for expatriates to achieve as it involved the modification of fundamental attitudes that were resistant to change. For instance, Lee and Larwood (1983) investigated the cultural socialization of American expatriate managers in Korea and found that their adjusted attitudes towards the host culture resulted in more satisfaction with their work. Berryp (1997) stressed that attitudes to the host national populations were important as they provided a favourable or unfavourable context in which acculturation processes played out and relations were developed. Intercultural attitudes such as cultural empathy, open-mindedness, social initiative, emotional stability and flexibility were expected to lead to successful adjustment to a new environment (Van Der Zee \& Van Oudenhoven, 2000). Feeling being not included, accepted or understood by the host people could disrupt the acculturation process and could lead to emotional problems (Sakurai, McCall-Wolf, \& Kashima, 2010; Zhang \& Brunton, 2007).

\subsection{Satisfaction with the Host Life}

Satisfaction with life, positive and negative affect was three components of subjective well-being (Andrews \& Withey, 1976). While positive and negative affect referred to emotional aspects, satisfaction referred to cognitive aspects (Neto, 1995). Many studies examined the various factors that influenced an expatriate's social satisfaction with the host life (Sam, 2001) the degree of psychological comfort with the various aspects of a host culture (Blacke \& Stephens, 1989) or the emotional status of expatriates (Folkman, Lazarus, DunkelSchetter, DeLongis, \& Gruen, 1986; Sam, 2001). Selmer (1999) found that while the work adjustment, interaction adjustment and general adjustment of the western expatriate business managers working in China showed a clear U-curve pattern indicating a typical culture shock experience, no pattern was displayed in the case of psychological adjustment as measured by their subjective well-being. Ward and Kennedy (1999) reported that strong co-national identification predicted enhanced psychological well-being of the international aid workers in Nepal. Cultural adjustment was enhanced by expatriates' satisfaction with their work and host country and job dissatisfaction was positively related with psychological suffering and physical health issues (Ramalu, Wei, \& Rose, 2011).

\subsection{The Demographic Factors}

Lots of researchers also studied the related individual factors influencing the sojourners adjustment in the foreign countries such as the acculturative experience, education status, gender, age and the length of stay in a foreign country (Kolaitis, 2003; Netos, 2002; Zimmermann, 1995). However, the relationships between demographic features of sojourners and their cross-cultural adjustment appeared to be inconsistent in different empirical studies. Some studies revealed that the problems perceived by male international students were not significantly different from those perceived by females (Moffett, 2006; Rhine, 1989); whereas, some found that female international students suffered more adjustment problems than their male counterparts (Dao, Lee, \& Chang, 2007). Others even showed that female students were at a higher level of adjustment than males (Williams, Waldauer, \& Duggal, 1992; Ying \& Han, 2006). Because of the gaps in the literature for understanding the diverse factors affecting expatriate cross-cultural adjustment, future research on cultural adjustment could explore differences in cultural adjustment between men and women to aid business leaders appoint the right gender to specific international assignments (Gazley, Chang, \& Bingham, 2010).

As for the effect of length of stay in the foreign country, contradictory findings have been made, too (Cheng \& Antony, 2012; Janssens, 1995; Schram \& Lauver, 1988; Waxin, 2004; Zimmermann, 1995). While no significant relationship between time spent in the host country and adjustment was found in a sample of Belgian and British expatriates (Janssens, 1995); (Waxin, 2004) found that time spent in the host country was positively and significantly related to the general adjustment for French expatriates. Cheng and Antony (2012) pointed out that students who stayed longer in the United States had the lowest anxiety, while Schram and Lauver (1988) found that the length of time in the U.S was not related to feelings of alienation. Zimmermann (1995) demonstrated that international students' length of stay in the U.S was not related to their perceptions of adjustment or their satisfaction with communication in the target culture environment. Therefore, time did not seem to be a sufficient predicator for facilitating adaptation (Zimmermann, 1995). Zimmermann (1995) also pointed out that no significant differences were identified between undergraduate and graduate students on any measure. In contrast to Zimmermann's finding, previous studies found that participants with higher education levels had more positive adaption, higher satisfaction (Tonsing, 2013) and less difficulties in negotiating daily social context in the host culture than those with lower education levels (Podrug, Kristo, \& Kovac, 2014). shock:

According to the above literature review, the following research questions were raised to address culture

Q1: Is severity of culture shock different in a cohort of Peace Corps volunteers with different length of stay in China?

Q2: How did gender and education background of Peace Corps volunteers affect their culture shock in China? 
Q3: What are the correlations between homesickness, feelings towards China, satisfaction with the life in China and culture shock?

\section{Method}

3.1. Participants

The participants were 154 Peace Corps volunteers from the universities in Sichuan, Gansu, Guizhou provinces and Chongqing Municipality in the western China. Among them, there were 98 females $(63.6 \%)$ and 56 males (36.4\%). The current sample had an average age of 24 years old (ranging from 22 to 31 years old). The average length of stay in China was more than one year ( $\mathrm{M}=1.77 ; \mathrm{SD}=0.68)$, with $43.5 \%(\mathrm{n}=67)$ indicating 0.6-1 year of residence in China, $56.5 \%(n=87)$ 1-3years of residence in China. 76 of the participants $(49.4 \%)$ were with bachelor degree and 78 of them $(50.6 \%)$ with master and $\mathrm{PhD}$ degree. All the participants had been trained for three months in China before they started to work. The training consisted of intensive language study, cross-cultural education, and the development of skills necessary for one's job assignment with the Peace Corps.

\subsection{Measurement}

Expatriate Adaptation Inventory (EAI) (Fukunishi, Wogan, Berger, \& Kuboki, 1999) was modified to measure Peace Corps volunteers' homesickness (10 items), feelings towards China (14 items) and satisfaction with the life in China (26 items). The EAI was tested to be reliable by Di (2004) ( $\mathbf{a}=0.81$ ), Ruslan (2016) ( a $=0.93)$ and its validity was checked and proven to be high (Ruslan, 2016) ( $\mathrm{X}^{2}=6.98, \mathrm{df}=2, \mathrm{X}^{2} / \mathrm{df}=3.49$, $\mathrm{p}=0.000<0.001)$. The internal consistency estimate of the current scale was $\mathrm{a}=0.92$ for the overall EAI and the three subscales showed satisfactory reliability respectively ( $a=0.81$ for the homesickness; $a=0.92$ for feelings towards China; $\mathbf{a}=.95$ for the satisfaction with life in China). Its validity construct was high (KMO $=0.601>0.5, \mathrm{df}=6, \mathrm{p}=0.000<0.001)$. The questionnaire was measured by a 5 -point Likert scale (from $1=$ strongly disagree to $5=$ strongly agree).

Culture Shock Questionnaire (Mumfordp, 1998) was taken and modified for the current study, the details of the internal consistency and external criterion validity can be found in Mumfordp (1998). The Questionnaire included 12 items. The internal consistency estimates of the current scale showed satisfactory reliability $(\mathrm{a}=.72)$. The questionnaire was measured by a 5 -point Likert scale (from $1=$ strongly disagree to $5=$ strongly agree).

The demographic information in this survey was gender, education background and the length of stay.

\subsection{Data Collection}

The questionnaire was first sent to the office of Peace Corps China in Chengdu, China to ask the colleagues to send invitation emails to all Peace Corps volunteers to fill in the survey. The total usable questionnaires were 154. The survey was carried out in English.

\section{Results}

4.1. How Did Length of Stay, Gender and Education Background of Peace Corps Volunteers Affect their Culture Shock in China?

In order to see if the demographic factors have effects on the culture shock of Peace Corps volunteers in China, independent sample T-test was taken to test how gender and education background variables affect culture shock. Table 1 showed that no significant difference was found between males and females on culture shock and there was statistical significant difference between the volunteers with bachelor degree and those with master and PhD degree, volunteers with bachelor degree experienced more culture shock than those with master and $\mathrm{PhD}$ degree.

Table-1. Independent sample T-test on culture shock by gender and education background.

\begin{tabular}{|c|c|c|c|c|c|c|c|c|}
\hline & Group & Mean & SD & $\begin{array}{c}\text { Mean } \\
\text { difference }\end{array}$ & $\mathbf{t}$ & df & $\begin{array}{l}\text { Sig. }(2- \\
\text { tailed) }\end{array}$ & $\mathbf{N}$ \\
\hline \multirow[t]{2}{*}{ Culture shock } & $\begin{array}{l}\text { Volunteers with } \\
\text { bachelor }\end{array}$ & 2.375 & .393 & \multirow[t]{2}{*}{.128} & \multirow[t]{2}{*}{1.985} & \multirow[t]{2}{*}{152} & \multirow[t]{2}{*}{.049} & 76 \\
\hline & $\begin{array}{c}\text { Volunteers with master } \\
\text { and PhD }\end{array}$ & 2.246 & .408 & & & & & 78 \\
\hline \multirow[t]{2}{*}{ Culture shock } & Female & 2.329 & .417 & \multirow[t]{2}{*}{-.067} & \multirow[t]{2}{*}{-.784} & \multirow[t]{2}{*}{152} & \multirow[t]{2}{*}{.434} & 98 \\
\hline & Male & 2.276 & .383 & & & & & 56 \\
\hline
\end{tabular}

Table 2 indicated that no significant difference was found between culture shock and different length of stay. 
Table-2. One way ANOVA of Peace Corps volunteers' culture shock by length of stay.

\begin{tabular}{c|c|c|c|c|c|c|c|c|c}
\hline & $\begin{array}{c}\text { Length of } \\
\text { stay }\end{array}$ & Mean & SD & SS & df & MS & F & Sig. & N \\
\hline Culture & O.6-1 year & 2.373 & .392 & .773 & 2 & .387 & 2.400 & .094 & 67 \\
shock & $1-3$ years & 2.297 & .448 & 24.324 & 151 & .161 & & & 87 \\
\hline
\end{tabular}

Correlation analysis see Table 3 showed that there were no correlations between gender, education background, length of stay and homesickness, feelings towards China, satisfaction with the life in China.

Table-3. Correlations between gender, education background, length of stay and homesickness, feelings towards china, satisfaction with the life in China.

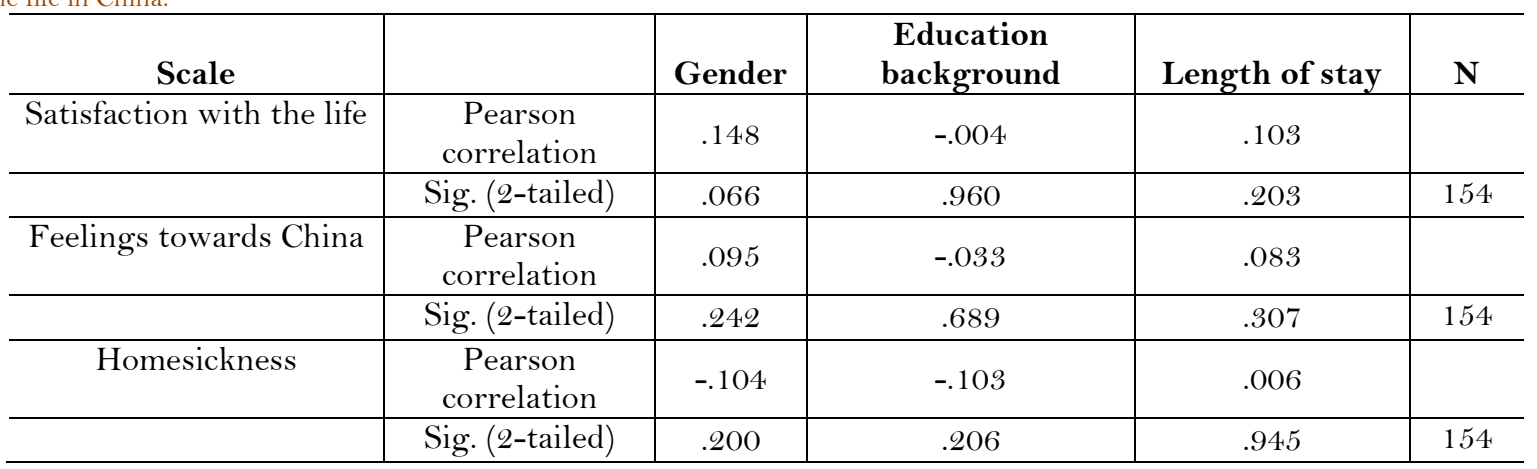

4.2. What are the Correlations between Culture Shock and Homesickness, Feelings towards China, Satisfaction with the Life in China?

4.2.1. Correlation Analysis

Pearson correlation analysis results see Table 4 indicated that there was correlation between culture shock and the other four variables. Culture shock was positively related with homesickness ( $\mathrm{r}=.571^{* *}$, $\mathrm{p}=.000<0.01)$ and was correlated negatively with feelings towards China $\left(\mathrm{r}=-.277^{*}, \mathrm{p}=.000<0.01\right)$, satisfaction with the life in China $\left(r=-.195^{*}, p=.015<0.05\right)$, and education background $\left(r=-.159^{*}, p=.049<0.05\right)$. That is, the more homesickness, the more culture shock. The more satisfaction with the life in China, the less culture shock the volunteers experienced and the higher education level, the less culture shock. Because the 14 items surveying feelings towards China were backward design suggesting negative statements, that is, the more negative feelings towards China, the more culture shock, vice versa. Among the correlations, homesickness was most correlated with culture shock, then feelings towards China, satisfaction with the life in China, and education background was the least correlated with culture shock. Results also indicated that culture shock was not significantly correlated with gender $(r=.063, p=.434>0.05)$ and length of stay $(r=-.064$, $\mathrm{p}=.427>0.05)$.

Table-4. Correlations between culture shock and homesickness, feelings towards china and satisfaction with the life in China

\begin{tabular}{|c|c|c|c|}
\hline Scale & Culture shock & Sig.(2-tailed) & $\mathbf{N}$ \\
\hline Homesickness & $.571(* *)$ & .000 & 154 \\
\hline Feelings towards China & $-.277(* *)$ & .000 & 154 \\
\hline Satisfaction with the life in China & $-.195(*)$ & .015 & 154 \\
\hline Education background & $-.159(*)$ & .049 & 154 \\
\hline Gender & .063 & .434 & 154 \\
\hline Length of stay & -.064 & .427 & 154 \\
\hline
\end{tabular}

\subsubsection{Multiple Linear Regression Analysis}

In order to further examine the relationship between culture shock and homesickness, feelings towards China, satisfaction with the life in China and education background, homesickness, feelings towards China, satisfaction with the life in China satisfaction with the life in China and education background were regarded as the independent variables and culture shock as the dependent variable. Multiple linear regression analysis was used to investigate which independent variables influenced culture shock most. Stepwise was used in the analysis and the results were showed on Table 5.

Table 5 showed that, among the four independent variables (homesickness, feelings towards China, and satisfaction with the life in China, education background), only homesickness and feelings towards China could enter the regression equation. Table 5 indicated that, 53.5\% of homesickness could predict the culture shock and $14.2 \%$ of feelings towards China could predict the culture shock. However, satisfaction with the life in 
China and education background could not enter the regression equation, which means that culture shock could be poorly predicated by satisfaction with the life in China and education background.

\begin{tabular}{l|c|c|c|c|c}
\hline \multirow{2}{*}{ Model } & \multicolumn{2}{c|}{$\begin{array}{c}\text { Unstandardized } \\
\text { coefficients }\end{array}$} & $\begin{array}{c}\text { Standardized } \\
\text { coefficients }\end{array}$ & \multirow{2}{*}{ Sig. } \\
\cline { 2 - 5 } & $\mathbf{B}$ & Std. error & Beta & & \\
\hline Homesickness $^{\mathrm{a}}$ & .266 & .033 & .535 & 7.863 & .000 \\
Feelings towards China $^{\mathrm{a}}$ & -.082 & .036 & -.142 & -2.091 & .026 \\
\hline Satisfaction with the life in China $^{\mathrm{b}}$ & .731 & .108 & .481 & 6.771 & .000 \\
\hline Satisfaction with the life in China $^{\mathrm{c}}$ & -.445 & .131 & -.266 & -3.401 & .001 \\
\hline
\end{tabular}

Note: a. Dependent variable: culture shock; b. dependent variable: feelings; c. dependent variable: homesickness.

\subsubsection{Path Analysis}

From the analysis above, culture shock could be poorly predicated by satisfaction with the life in China and education background. However, as Table 4 showed, culture shock was significantly correlated with satisfaction with the life in China and education background. Analysis of Stepwise Multiple Regression did not make it clear that how satisfaction with the life in China and education background influenced culture shock. The possible hypothesis is that satisfaction with the life in China and education background were indirectly correlated with culture shock, probably satisfaction with the life in China and education background influenced culture shock through feelings towards China and homesickness. In order to test this hypothesis, path analysis was used to analyze the data. The hypothesis was first designed into a path diagram without path coefficient see Figure 1.

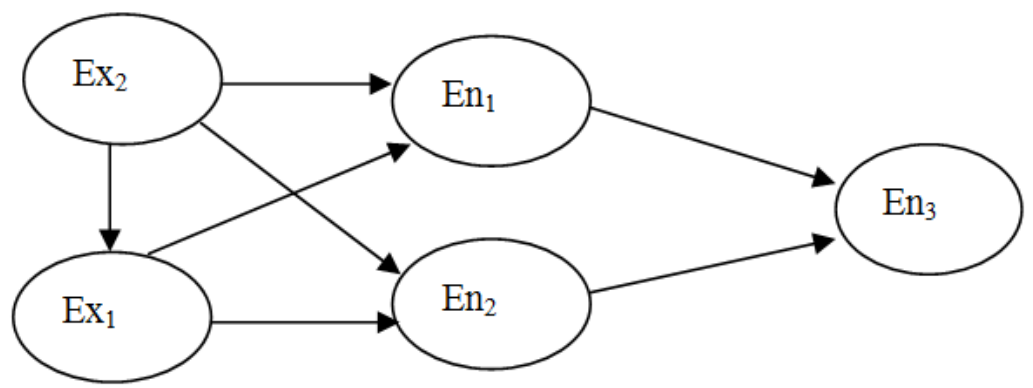

Figure-1. Path analysis of the hypothesis.

Note: $\mathrm{Ex}_{1}=$ satisfaction with the life in China; $\mathrm{Ex}_{2}=$ education background.

$\mathrm{En}_{1}=$ homesickness; $\mathrm{En}_{2}=$ feelings feelings towards China; $\mathrm{En}_{3}=$ culture shock.

In the Figure 1 above, the exogenous variable $1\left(\mathrm{Ex}_{1}\right)$ and exogenous variable $2\left(\mathrm{Ex}_{2}\right)$ were modelled as being correlated and as having indirect effects on $\mathrm{En}_{3}$ through $\mathrm{En}_{1}$ and $\mathrm{En}_{2}$. Culture shock could be influenced by the four independent variables (homesickness, feelings towards China, satisfaction with the life in China, education background) through 7 paths. Among which, homesickness and feelings towards China had direct effects on culture shock; Satisfaction with the life in China and education background could have effects on culture shock through five paths: satisfaction with the life in China and education background had indirect effects on culture shock through feelings towards China and homesickness, and education background had indirect effects on culture shock through satisfaction with the life in China.

In order to calculate each path coefficient in Figure 1, four regression analyses were forced to enter: 1) Culture shock was the dependent variable, homesickness, feelings towards China, satisfaction with the life in China and education background, were independent variables; 2) Feelings towards China was the dependent variable, satisfaction with the life in China and education background was independent variables; 3) Homesickness was the dependent variable, satisfaction with the life in China and education background were independent variables; 4) Satisfaction with the life in China was the dependent variable, and education background was the independent variable.

The path analysis coefficients are Standardized Coefficients (Beta). Table 5 showed that, when culture shock was the dependent variable, feelings towards China, homesickness and satisfaction with the life in China were independent variables, the Standardized Coefficients of the independent variables were Beta $=.535$ (homesickness, $\mathrm{p}=.000<0.05$ ), -.142 (feelings towards China, $\mathrm{p}=.000<0.05$ ), and satisfaction with the life in China (Beta In $=-.047, \mathrm{t}=-.676, \mathrm{p}=.500>0.05$ ) and education background (Beta $\mathrm{In}=-.101, \mathrm{t}=-1.522$, $\mathrm{p}=.130>0.05)$ were excluded; when feelings towards China was the dependent variable, satisfaction with the life in China and education background were independent variables, the Standardized Coefficients was Beta $=.481$ (satisfaction with the life in China, $\mathrm{p}=.000<0.05$ ), education background (Beta In=-.033, $\mathrm{t}=-.429$, $\mathrm{p}=.689>0.05)$ was excluded; when homesickness was the dependent variable, satisfaction with the life in China and education background were independent variables, the Standardized Coefficients (Beta) of the independent 
variable was Beta=-.266 (satisfaction with the life in China, $\mathrm{p}=.000<0.05$ ), education background (Beta In=$.104, \mathrm{t}=-.1 .329, \mathrm{p}=.186>0.05$ ) was excluded: When satisfaction with the life in China was the dependent variable, education background was independent variables, the Standardized Coefficients (Beta) of the independent variable was Beta In=-.004 ( $\mathrm{t}=-.050, \mathrm{p}=.960>0.05)$. The results of the Standardized Coefficients could be added to the path model see Figure 2.

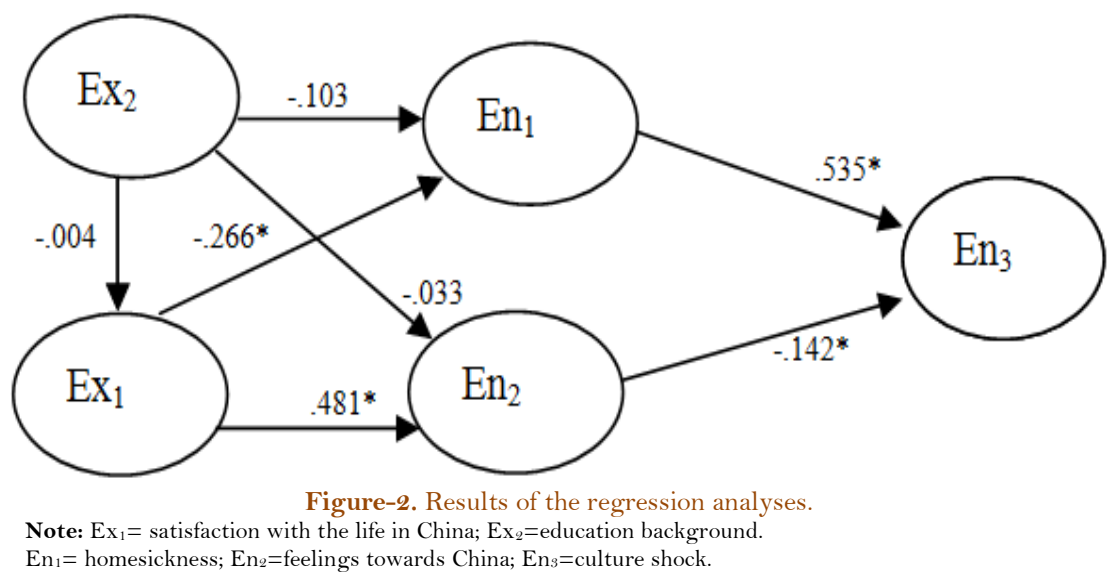

From the Figure 2 Standardized Coefficients indicated that there were four paths which showed how culture shock was influenced. The first was homesickness $\rightarrow$ culture shock; the second was feelings towards China $\rightarrow$ culture shock; the third was satisfaction with the life in China $\rightarrow$ homesickness $\rightarrow$ culture shock; the fourth was satisfaction with the life in China $\rightarrow$ feelings towards China $\rightarrow$ culture shock. Therefore, homesickness and feelings towards China could be regarded as mediating variables. Satisfaction with the life in China had indirect effect on culture shock through feelings towards China and homesickness. Feelings towards China and homesickness had direct effects on culture shock. The analysis proved the above mentioned hypothesis except the hypothesis that education background had indirect effect on culture shock.

\section{Discussion}

The current study examined the factors predicting the culture shock of Peace Corps volunteers in the universities in the western China. It aimed to clarify the theoretical connections between demographic variables, homesickness, feelings towards host culture, satisfaction with the life in the host culture and culture shock.

\subsection{Demographic Factors and Culture Shock}

The result of this study revealed that length of stay was not a significant predictor for culture shock. According to the U-curve, stages and symptoms of culture shock should vary greatly over the time. However, the result of the present study could not support the U-curve. This result further evidenced the previous studies in which no significant relationship between time spent in the host country and adjustment was found (Janssens, 1995) and that the length of time was not related to feelings of alienation (Schram \& Lauver, 1988) and to the perceptions of adjustment or the satisfaction with communication in the target culture environment of the international students (Zimmermann, 1995). The explanations for the current result probably could be that the average length of stay in China was more than one year with $43.5 \%$ and 56.5 of the participants indicating 0.6-1year of residence and 1-3years of residence in China. Most of Peace Corps in China usually signed two-year's contract, but previous study indicated that the adjustment stage was only reached after two years in the host countries (Tange, 2005). Another possible explanation is that the length of stay in the host culture may not guarantee that individuals are willing or have ways to learn the host social norms and rules (Chapdelaine \& Alexitch, 2004). Though no significant difference was not found between length of stay and culture shock, length of stay in this study showed a negative predictive effect on culture shock, which means that the longer stay in the host culture could reduce the degree of culture shock which was consistent with some other studies (Paul, 2003; Wards, 1996; Waxin, 2004).

Education background was a significant negative predictor for culture shock for Peace Corps volunteers in China. This indicated that participants with higher education background had lower culture shock. This was similar to Tonsing (2013) which found that participants with higher education background had more positive adaptation and higher life satisfaction. Podrug et al. (2014) also found that Croatian expatriates who obtained graduate degree had less difficulty in managing daily social situation in the new culture context than those who had undergraduate degree. Education background was found to be an influential factor for negative culture shock, possibly because as a personal resource, education played an important role in an individual's construction of self- esteem (Tonsing, 2013) and it was also probable that people with higher education also 
had requisite social skills and culture-specific knowledge which enabled them to manage specific social situations and function effectively in the host culture (Mumford, 2000; Tonsing, 2013). Higher education could also help to deal with culture shock phenomenon as a problem in 'culture learning' (Furnham \& Bochner, 1982).

The result also indicated that gender was less relevant to culture shock. It was possibly because the participants' gender could not be easily changed and hence showed less contributing effect in predicting culture shock and this indicated that culture shock was more influenced by other factors (Tonsing, 2013) such as homesickness, feelings towards host culture, satisfaction with the life in the host culture and some other social factors.

\subsection{Homesickness, Feelings towards Host Culture, Satisfaction with the Life in the Host Culture and Culture Shock}

A strong correlation was found between Peace Corps volunteers' culture shock and homesickness. Homesickness accounted for $53.5 \%$ of the variance in culture shock. This result was consistent with the previous findings of socio-cultural difficulties experienced by the international students (Furnham \& Bochner, 1982; Searle \& Ward, 1990; Ward \& Kennedy, 1993) and was similar to Ward and Kennedy (1993) in which they found homesickness, external lotus of control, life changes and social difficulty could explain $55 \%$ of the variance in psychological adjustment of the New Zealand American Field Service students. However, in contrast to previous studies, the culture shock questionnaire used in the current study focused exclusively on the subjective feelings relating to the experience in adaptation to another new culture. Results also indicated that culture shock was mainly influenced by missing "friends and home country" $(\mathrm{M}=3.448, \mathrm{r}=.317, \mathrm{p}<0.01)$, "the food of home country." ( $\mathrm{M}=3.454, \mathrm{r}=.432, \mathrm{p}<0.01)$, "the customs and ways of doing things at home." $(\mathrm{M}=3.118, \mathrm{r}=.448, \mathrm{p}<0.01)$, "the media (radio, TV, newspapers, etc.) from home." (M=3.097 $\mathrm{r}=.458$, $\mathrm{p}<0.01$,$) , the customs and ways of doing things at home (\mathrm{M}=3.136, \mathrm{r}=.448, \mathrm{p}<0.01)$. This implied that homesickness might bring about culture shock which coincided with the finding that homesickness resulted in distress or depression (Stroebe, Van Vliet, Hewstone, \& Willis, 2002). The degree of missing friends, families, food, medias and customs of home country might lead to feel lonely and loneliness was linked to depression (Stroebe et al., 2002). Therefore, homesickness became a sign of culture shock when the missing of the familiarity of home country reached the level of depression and anxiety, dissatisfaction and negative feelings. This might be due to great cultural differences between China and the U.S which caused more homesickness and stronger culture shock (Eurelings-Bontekoe, Brouwers, \& Verschuur, 2000; Yeh \& Inose, 2003).

Feelings toward China also were found to be correlated directly to Peace Corps volunteers' culture shock in China. Feelings towards China could account for $26.6 \%$ of variance in culture shock. The negative feelings of Peace Corps volunteers experienced in China seemed to have a marked effect on their experience of culture shock. Though the volunteers had more positive feelings toward China, their negative experiences in China might happen because the cultural and language differences were likely to make them experience negative discrimination which was associated with culture shock (Poyrazli \& Lopez, 2007). The results showed that feelings towards China could account for only $26.6 \%$ of variance in culture shock. The possible reasons might be that (1) all Peace Corps volunteers in the survey were trained for three months in China and stayed with the Chinese family before they started to work; (2) Peace Corps volunteers were trained regularly by the experienced Peace Corp faculty and volunteers during their work in China; (3) Peace Corps volunteers in the survey worked in the universities in western China, where most of their students and Chinese colleagues could speak English which further reduced their culture shock. This result also further supported the idea that teachers who received prior training or in-service training could get advice and support to alleviate culture shock symptoms (Deveney, 2007).

Another finding in this study was that satisfaction with the life in China had indirect effect on culture shock with feelings towards China and homesickness as mediating variables. Multiple Regression Analysis showed that satisfaction with the host life had a negative relation with homesickness and a positive with feelings towards host life. That was to say, the more satisfaction with the host life, the less homesickness and culture shock; and the more satisfaction with the host life, the less negative feelings towards host country and culture shock, vice versa. The finding may be understood in the way that homesickness and feelings towards China are related to emotional aspects, and satisfaction with life in China refers to cognitive aspects (Neto, 1995). This indicated that the nature of culture shock is more influenced by the emotional factors other than cognitive factors.

\section{Future Research}

Overall, the current study investigated the factors that predicted the culture shock of Peace Corps volunteers in the universities in the western China in terms of homesickness, feelings towards China, satisfaction with the life in China, gender, education levels and length of stay. The participants in this study were Peace Corps volunteers in China, all of them worked in the colleges and universities in the west of China which were located in the medium-sized or big cities. Therefore, their experiences of culture shock might be different from the volunteers who worked in the small villages in other parts of the world. What's more, all Peace Corps volunteers had been trained for three months in China before they started to work. Future 
research needs to do more comparison about the influence of the prior working experiences abroad and motivation of being a volunteer on culture shock. And more research could be done on the comparison of culture shock experienced by the prior trained expatriates and those with no prior training.

\section{References}

Adler, P. (1975). The transitional experience: An alternative view of culture shock. Journal of Humanistic Psychology, 15(4), 13-23.

Andrews, F. M., \& Withey, S. B. (1976). Social indicators of well-being. New York: Plenum.

Argyle, M., Furnham, A., \& Graham, J. A. (1981). Social situations. Cambridge, UK: Cambridge University Press.

Becker, S. W., \& Eagley, A. H. (2004). The heroism of men and women. American Psychologist, 59(3), 163-178.

Berry, J. W. (1990). Psychology of acculturation. In R. W. Brislin (Ed.), Applied Cross-Cultural Psychology (pp. 232-253). Newbury Park, CA: Sage.

Berrye, J. W., Kim, U., \& Boski, P. (1988). Psychological acculturation of immigrants. In Y.X. Kim \& W.B. Gudykunst (Eds), Cross-cultural Adaptation: Current Approaches. Newbury Park, CA: Publications.

Berryp, J. (1997). Immigration, acculturation and adaptation. Applied Psychology: An International Review, 46(1), 5-34.

Black, J. S., \& Gregersen, H. B. (1990). Expectations, satisfaction and intentions to leave of American managers in Japan. International Journal of Intercultural Relation, 14(4), 485 - 506.

Blacke, J. S., \& Stephens, G. K. (1989). The influence of the spouse on American expatriate adjustment and intent to stay in Pacific Rim overseas assignments. Journal of Management, 15(4), 529-544.

Bock, P. K. (1970). Culture shock: A reader in modern cultural anthropology (Ed.). New York: Knopf.

Brewin, C., Furnham, A., \& Howes, M. (1989). Demographic and psychological determinants of homesickness and confiding among students. British Journal of Psychology, 80(4), 467-477.

Byrnes, F. C. (1966). Role shock: An occupational hazard of American technical assistants abroad. Annals of the American Academy of Political and Social Science, 368(1), 95-108.

Carano, K. (2013). An auto ethnography: Constructing (\& Interpreting) cross-cultural awareness through the mind of a Peace Corps volunteer (Vol. 18, pp. 1-15). The Qualitative Report.

Castro, V. (2003). Acculturation and psychological adaptation. Westport, CT: Greenwood Press.

Chapdelaine, R. F., \& Alexitch, L. R. (2004). Social skills difficulty: Model of culture shock for international graduate students. Journal of College Student Development, 45(2), 167-184.

Cheng, R., \& Antony, E. (2012). Language anxiety: Experiences of Chinese graduate students at U.S. higher institutions. Journal of Studies in International Education, $16(5), 477-497$.

Church, A. T. (1982). Sojourner adjustment. Psychological Bulletin, 91(3), 540-572.

Dao, T. K., Lee, D. H., \& Chang, H. L. (2007). Acculturation level, perceived English fluency, perceived social support level, and depression among Taiwanese international students. College Student Journal, 41 (2), 287-295.

Deveney, B. (2007). How well-prepared do international school teachers believe themselves to be for teaching in culturally diverse classrooms? Journal of Research in International Education, 6(3), 309-332.

Di, S. (2004). The International students' cross-cultural adaptation in China. Unpublished Master Dissertation, Nan Jin Normal University, China.

Eurelings-Bontekoe, E. H. M., Brouwers, E. P. M., \& Verschuur, M. J. (2000). Homesickness among foreign employees of a multinational high-tech company in the Netherlands. Environment and Behavior, 32(3), 443-456.

Folkman, S., Lazarus, R. S., Dunkel-Schetter, C., DeLongis, A., \& Gruen, R. J. (1986). Dynamics of a stressful encounter: cognitive appraisal, coping, and encounter outcomes. Journal of Personality and Social Psychology, 50(5), 992-1003.

Fukunishi, I., Wogan, J., Berger, D., \& Kuboki, T. (1999). Alexithymic traits as predictors of difficulties with adjustment in an outpatient cohort of expatriates in Tokyo. Psychological Reports, 85(1), 67-77.

Furnham, A., \& Bochner, S. (1982). Social difficulty in a foreign country: An empirical analysis of culture shock. In S. Bochner, Cultures in contact - studies in cross-cultural interaction. Oxford: Pergamon.

Furnham, A., \& Bochner, S. (1986). Culture shock: Psychological reactions to unfamiliar environments. London: Methuen.

Gazley, B., Chang, W. K., \& Bingham, L. B. (2010). Board diversity, stakeholder representation, and collaborative performance in community mediation centers. Public Administration Review, 70(4), 610-620.

Gullahorn, J. T., \& Gullahorn, J. E. (1963). An extension of the U-curve hypothesis. Journal of Social Issues, 19(3), 33-47.

Guthrie, G., \& Dan, Z. (1967). Predicting performance in the peace corps. Journal of Social Psychology, 71(1), 11- 21.

Guthries, G. M. (1975). A behavioral analysis of culture learning. In R. W. Brislin, S. Bochner, \& W. J. Lonner (Eds.), Cross-cultural perspectives on learning (pp. 95-115). New York: Sage.

Hare, P. (1966). Factors associate with Peace Corps volunteer success in the Philippines. Human Organization, 25(2), 150153.

Hendrickson, B., Rosen, D., \& Aune, K. (2010). An analysis of friendship networks, social connectedness, homesickness, and satisfaction levels of international students. International Journal of Intercultural Relations, 35(3), $281-295$.

Hsiao-Ying, T. (1995). Sojourner adjustment: The case of foreigners in Japan. Journal of Cross-Cultural Psychology, 26(5), 523-536.

Hull, W. F. (1978). Foreign students in the United States of America: Coping behavior within the educational environment. New York: Praeger.

Janssens, M. (1995). Intercultural interaction: a burden on international managers? Journal of Organizational Behavior, 16(2), 155-167.

Kim, B. S., Atkinson, D. R., \& Umemoto, D. (2001). Asian cultural values and the counseling process: Current knowledge and directions for future research. The Counseling Psychologist, 29(4), 570-603.

Kleinberg, O., \& Hull, W. (1979). At a foreign university: An international study of adaptation and coping. New York: Praeger.

Kolaitis, G. P. (2003). Psychosocial adaptation of immigrant Greek children from the former Soviet Union. European Child and Adolescent Psychiatry, $12(2), 67-74$. 
Lee, Y., \& Larwood, L. (1983). The socialization of expatriate managers in multinational firms. Academy of Management Journal, 26(4), 657-665.

Lysgaard, S. (1955). Adjustment in a foreign society: Norwegian Fulbright grantees visiting the United States. International Social Science Bulletin, 7(1), 45-51.

Messina, J. (2007). Helping students cope with homesickness. University Business, 116(10), 80-180.

Moffett, D. W. (2006). A phenomenological study of international students in a Florida university Ph. D. program. Paper presented at the Paper Presented At the Florida Educational Research Association (FERA) Annual Meeting, November, 2006, Jacksonville, Florida USA.

Mori, S. C. (2000). Addressing the mental health concerns of international students. Journal of Counseling \& Development, $78(2), 137-144$.

Mumford, D. B. (2000). Culture shock among young British volunteers working abroad: Predictors, risk factors and outcome. Transcultural Psychiatry, 37(1), 73-87.

Mumfordp, D. (1998). The measurement of culture shock. Social Psychiatry, 33(4), 149-154.

Neto, F. (1995). Predictors of satisfaction with life among second generation migrants. Social indicators research, 35(1), 93116.

Netos, F. (2002). Social adaptation difficulties of adolescents with immigrant backgrounds. Social Behavior and Personality: An International Journal, 30(4), 335-345.

Oberg, K. (1960). Cultural shock: Adjustment to new cultural environments. Practical Anthropology, 7(3), 177-182.

Paul, N. L. (2003). Acculturation: A review of the literature. Intercultural Communication Studies, 12(2), 103-1 18.

Peace Corps China. (2016). Retrieved from https://www.peacecorps.gov/china/.

Podrug, N., Kristo, M., \& Kovac, M. (2014). Cross-cultural adaptation of croatian expatriates. Ekonomski Pregled, 65(5), 453-472.

Poyrazli, S., \& Lopez, M. D. (2007). An exploratory study of perceived discrimination and homesickness: A comparison of international students and American students. The Journal of psychology, 141(3), 263-280.

Ramalu, S. S., Wei, C. C., \& Rose, R. C. (2011). The effects of cultural intelligence on cross-cultural adjustment and job performance amongst expatriates in Malaysia. International Journal of Business and Social Science, 2(9), 59-71.

Rhine, S. L. (1989). The effect of state mandates on student performance. The American Economic Review, 79(2), 23 1-235.

Ruslan, T. (2016). Cultural adaptation of Russian students in China and Chinese students in Russia. Unpublished Master Dissertation, East China Normal University, China.

Sakurai, T., McCall-Wolf, F., \& Kashima, E. (2010). Building intercultural links: The impact of a multicultural intervention programme on social ties of international students in Australia. International Journal of Intercultural Relations, $34(2), 176-185$

Sam, D. L. (2001). Satisfaction with life among international students: An exploratory study. Social Indicators Research, 53(3), 315-337.

Sandhu, D. S., \& Asrabadi, B. R. (1994). Development of an acculturative stress scale for international students: Preliminary findings. Psychological Reports, 75(1), 435-448.

Schram, J. L., \& Lauver, P. J. (1988). Alienation in international students. Journal of College Student Development, 29(2), 146150 .

Searle, W., \& Ward, C. (1990). The prediction of psychological and sociocultural adjustment during cross-cultural transitions. International Journal of Intercultural Relations, 14(4), 449-464.

Selmer, J. (1999). Culture shock in China?: Adjustment pattern of western expatriate business managers. International Business Review, 8(5-6), 515-534.

Shi, L., \& Wang, L. (2014). The culture shock and cross-cultural adaptation of Chinese expatriates in international business contexts. International Business Research, 7(1), 23.

Smalley, W. A. (1963). Culture shock, language shock, and the shock of self-discovery. Practical Anthropology, 10(2), 49-56.

Stroebe, M., Van Vliet, T., Hewstone, M., \& Willis, H. (2002). Homesickness among students in two cultures: Antecedents and consequences. British Journal of Psychology, 93(2), 147-168.

Sumer, S. (2009). International students' psychological and socio-cultural adaptation in the United States. Counseling and Psychological Services Dissertations.

Taft, R. (1977). Coping with unfamiliar cultures. In: Warren N (eds) Studies in cross-cultural psychology (Vol. 1, pp. 121153). London: Academic Press.

Tange, H. (2005). In a cultural mo man's land-. Journal of Intercultural Communication, 10(2), 2-11.

Tonsing, K. N. (2013). Predictors of psychological adaptation of South Asian immigrants in Hong Kong. International Journal of Intercultural Relations, 37(2), 238-248.

Van Der Zee, K. I., \& Van Oudenhoven, J. P. (2000). The multicultural personality questionnaire: A multidimensional instrument of multicultural effectiveness. European Journal of Personality, 14(4), 291-309.

Ward, C., \& Kennedy, A. (1992). Locus of control, mood disturbance, and social difficulty during cross-cultural transitions. International Journal of Intercultural Relations, 16(2), 175-194.

Ward, C., \& Kennedy, A. (1993). Psychological and socio-cultural adjustment during cross-cultural transitions: A comparison of secondary students overseas and at home. International Journal of Psychology, 28(2), 129-147.

Ward, C., \& Kennedy, A. (1999). The measurement of sociocultural adaptation. International Journal of Intercultural Relations, 23(4), 659-677.

Wards, C. (1996). Acculturation. In D. Landis, \& Bhagat, R. S., Handbook of Intercultural of Training (Eds.) (pp. 124-147). Thousand Oaks, CA: Sage.

Waxin, M. F. (2004). Expatriates' interaction adjustment: The direct and moderator effects of culture of origin. International Journal of Intercultural Relations, 28(1), 61-79.

Williams, M. L., Waldauer, C., \& Duggal, V. G. (1992). Gender differences in economic knowledge: An extension of the analysis. The Journal of Economic Education, 23(3), 219-231. 
Winkelman, M. (1994). Cultural shock and adaptation. Journal of Counseling \& Development, 73(2), 12 1-126.

Yeh, C. J., \& Inose, M. (2003). International students' reported English fluency, social support satisfaction, and social connectedness as predictors of acculturative stress. Counselling Psychology Quarterly, 16(1), 15-28.

Ying, Y.-W., \& Han, M. (2006). The contribution of personality, acculturative stressors, and social affiliation to adjustment: A longitudinal study of Taiwanese students in the United States. International Journal of Intercultural Relations, 30(5), 623-635.

Yu, L., \& Huat, G. S. (1995). Perceptions of management difficulty factors by expatriate hotel professionals in China. International Journal of Hospitality Management, 14(3-4), 375-388.

Zhang, Z., \& Brunton, M. (2007). Differences in living and learning: Chinese international students in New Zealand. Journal of Studies in International Education, 11(2), 124-140.

Zimmermann, S. (1995). Perceptions of intercultural communication competence and international student adaptation to an American campus. Communication Education, 44(4), 32 1-335. 